\title{
Nature as Source of Inspiration and Peace for John Clare
}

\section{Mohan Raj Gouli, PhD}

Associate Professor, Nepal Sanskrit University

Visiting Faculty, Nesfield International College

Email: mohangouli@gmail.com

\begin{abstract}
John Clare has established himself as a poet of nature and his relationship with nature is to acknowledge the value of natural world for the wellbeing of human beings. Clare gets peace and strength when he surrenders himself into the lap of nature. Whenever he experiences unbearable pain and obstacles, he tends to communicate with nature dealing with its different shades to find the ways to tackle his problems. This article, through the lance of ecocriticism, aims to depict Clare's efforts to maintain harmonious relationship with nature to lead meaningful and peaceful life in this world.
\end{abstract}

Keywords: harmony, peace, nature, ecology, identity

John Clare displays the importance of nature's activities in the life of human beings and he attempts to persuade people to recognize the significance of natural world to uplift their life. His conviction shows that nature is the real source of energy which human beings can acquire without spending too much wealth or anything else. Clare's poetry deals with nature's extraordinary contribution to the people in spite of their indifferent attitude towards it. He presents different shades of nature and its changing aspects along with the description of seasons and natural beauty. Sometimes nature appears to be protective toward people and at other times it showers its encouraging and inspiring blessings upon people who are isolated by known and unknown human beings. Nature is also taken as a source of love and kindness for Clare. In "I AM," Clare writes:

I long for scenes, where man hath never trod,

A place where woman never smiled or wept-

There to abide with my Creator, God,

And sleep as I in childhood sweetly slept,

Untroubling, and untroubled where I lie,

The grass below-above the vaulted sky. (13-18)

He is longing for real natural beauty which is away from human beings' encroachment. Both men and women are the obstacles in his mission. Smiles and cries of are not meaningful for him. Since he was troubled by his fellow beings, he is longing for peaceful place and eventually expresses his desire to sleep like a child who is free from 
anxiety and trouble making activities. The images of grass and sky evoke strong security in his life. They inspire him to overcome anxieties and problems that come in course of his life.

Clare's poetry speaks about how nature is a source of inspiration and peace for the people. He explains that it is experienced by everyone who is in adverse situation in their life. When such persons have no one to console and support them in any adverse condition, only nature can sooth them with harmony and benevolent situation. Clare's "Song: Love Lives beyond the Tomb," communicates:

'Tis heard in spring

When light and sunbeams, warm and kind,

On angel's wing

Brings love and music to the wind. (13-16)

When love is absent in the life of speaker, he experiences adversity and begins to move here and there in search of his supporters to be cared and looked after. But his hope of getting such people is not fulfilled and he feels as if he is in hell among the people. Therefore, Clare imagines the season spring and gets joys and happiness with the presence of sun rays blessing him with kindness and love. He feels as if he is received in the heaven where even the wind plays music in the presence of angels. He expresses his faith in nature:

'Tis seen in flowers,

And in the even's pearly dew

On earth's green hours,

And in the heaven's eternal blue. (9-12)

Clare sees the presence of love and kindness in natural activities, for there is absence of any hidden selfish motives to deceive others. Dew drops resemble precious ornaments and green scenes of the earth evoke the heavenly atmosphere in this world.

Clare tries to establish strong affinity between nature and human beings. He beautifully creates such scenes that evoke how proper understandings between nature and people can be well established. In his poem "Gypsies," Clare sings how the gypsy helps a material boy to work with the snow:

The snow falls deep; the forest lies alone;

The boy goes hasty for his load of brakes,

Then thinks upon the fire and hurries back;

The gypsy knocks his hands and tucks them up,

And seeks his squalid camp, half hid in snow, 
Beneath the oak which breaks away the wind,

And bushes close in snow like hovel warm; (1-7)

The boy cannot adjust himself in the cold weather and he is not able to work with "his load of brakes" and seeks for the ways to warm him. He is capable to tolerate the effect of snow fall and fails to go ahead in his mission. On the other hand, gypsies are used to work with such environment and the boy here is immediately helped by one of them. He takes the boy to his dwelling place which is "snow like hovel warm" that speaks about proper adjustment with nature and natural environment in the life to survive and lead our successful life without getting any adverse effect on this earth. The boy "feels the heat too strong" (10) and he learns from the gypsy about how to protect from cold and move forward doing the work successfully.

Clare's understanding of nature is extraordinary because he develops different feelings about nature and natural elements, "[F] or my part I love to look on nature with a poetic feeling which magnifies the pleasure I love to see the nightingale in its hazel retreat \& the cuckoo hiding in it solitudes of oaken foliage \& not to examine their carcasses in glass cases" (Finch and Elder 125). He desires to experience live happenings of them. His anticipation to experience nature directly strengthens the idea about his love for nature and ecological concept.

Clare's happiness is generated when he happens to see the insects and flowers in the lap of nature. He is always curious to watch them and he, of course, feels dejected if he spends long time without seeing them in his daily life:

I have none of his curiosity about me [though] I feel as happy as they can about finding a new species of field flower of butterfly which I have not seen before yet I have no desire further to dry the plant or torture the butterfly by sticking it on a cork board with a pin - I have no wish to do this if my feelings would let me I only crop the blossom of the flower or take the root from its solitudes if it would grace my garden $\&$ wish the fluttering butterfly to settle till I can come up with it to examine the powdered colors on its wings. (125)

He celebrates his happiness to be in the companion of the insects and flowers in the field. His curiosity is concentrated on such things which enjoy freedom of natural environment and he too anticipates going along with them to continue to be with the "feelings" of happiness. He intensely desires "the fluttering butterfly to settle" in his garden.

Clare's deep interest in peasant life inspired him to compose poems about nature and natural surroundings. His "direct experience of rural life" (122) is evidently seen in his poetry and it is very important aspect of Clare's treatment with nature or ecological 
aspects as shown his writings. He creates "ecological vision" (Rueckert 118) in his expression. He talks about ants:

It has been commonly believed notion among [the] naturalists that trusts to books \& repeats the old error that ants hurd up \& feed on the cornels of grain such as wheat $\&$ barely but every common observer knows this to be a falsehood I have noticed them minutely \& often \& never saw one with such food in its mouth they feed on flyes $\&$ caterpillars which I have often seen them tugging home with $\&$ for which they climb trees \& the stems of flowers - when they first appear in the spring they may be seen carrying out ants in their mouths of a smaller size which they will continue to do a long time transporting them away from home perhaps to form their colonys - they always make a track \& keep it \& will go for furlongs away from their homes. (127)

Clare easily challenges the naturalists who tend to perform their research work depending upon written documents and try to prove their hypothesis repeating lapses about the ants and their behavior in nature. His close observation defies the notion "that ants hurd up \& feed on the cornels of grain such as wheat \& barely" as believed by the naturalists. His observation proves that they "feed on flyes \& caterpillars." Clare also observes and collects exact information how the adult ants carry the young ones and form their new homes in spring.

John Clare finds close relationship between ants and human beings. These creatures know to move forward being in harmony with the nature. In spite of adverse situation and any kind of predicaments, they adjust themselves in such natural environment. These creatures' presence and activities provide ample information and inspiration for the people to make their life comfortable and safer in accordance with the change in nature. Clare writes:

[I]t is commonly believed by careless observers that every hillock on greens \& commons has been first rooted up \& afterwards occupied by these little tenants but on the contrary most of the hills they occupy are formed by themselves which they increase every year by bringing up a portion of mold on the surface finely powdered on which they lay their eggs to receive the warmth of the sun $\&$ the shepherd by observing their wisdom in this labour judges correctly of the changes of the weather. (128)

Clare attacks the researchers who do not base their works on observation; rather they speak working and depending on others' published materials. His minute observation brings the conclusion that those ants labour hard and their labour is continuous to 
safeguard their settlement and identity along with their generation in new places. These creatures, Clare opines, inspire the shepherds to judge "correctly of the changes of the weather." In Cornel West's words, it is "well enough to give us a sense of possibility" (1017). Here it is the possibility of getting inspiration to maintain our dignity in our life.

Clare emphasizes on the universal appeal that human beings should be aware of the importance of nature to minimize forthcoming disasters that may occur in case of neglecting nature's significance to safeguard the life of people. Alan Bewell argues:

Clare's poetry provides a glimpse of the ecological and social impact that this change had upon the lives of English rural laborers, but we need not limit the context of our understanding of Clare to England. English rural laborers were not the only people who lost their traditional nature during this period.... Clare's poetry can also give us some idea of what it might have meant to other people in other parts of the world who were also grappling with the catastrophic loss of their own local natures. (552)

Bewell explores John Clare's vision carried by "the ecological and social impact" and favours his concept of preserving "traditional nature" so that people on earth will not be bound to precipitate into the disaster invited by the destruction of the environment. Bewell further explores, "Clare grew up knowing only one nature: the mixture of arable land, woodland, limestone heath, meadows, and fen that made up his native rural parish of Helpston" where according to David Bonnell Green, "he passed into a state of depression and idleness" $(550,723)$ perhaps to see the destruction of environmental degradation created by human beings over there.

Clare admits that people can achieve inspiration and peace from nature when they attempt to experience it. He feels that his value and identity can only be strengthened when he whole heartedly surrenders to the nature by experiencing through extensive journey of different places on the regular basis. He urges to explore new places and scenes through his own experiences:

I got out of my knowledge when the very wild flowers seem[e]d to forget me \& I imagin[e]d they were the inhabitants of new countr[ies]. The very sun seem[e]d to be a new one $\&$ shining in a different quarter of the sky. . . I was finding new wonders every minute $\&$ was walking in a new world \& expecting the world's end bye \& bye but it never came. (qtd. in Bewell 551)

He gets himself lost when he encounters "the very wild flowers" in new places in course of his journey in experiencing and exploring the scenes of different places that hold the 
natural environment. Even the sun appears to be new and strange to him when he happens to see it from different places.

Clare's attachment with nature and with different natural scenes has been beautifully described by John Barrell. He "provide[s] the first major theorization of the importance of "place" and "locality" in Clare's poetry" (Bewell 552-553). Clare's concern regarding local heritage of nature's gift appears to be extraordinary for human civilization at present as well future generation. Berrell writes:

$[\mathrm{M}]$ obility was an essential condition of the attitude we have been examining: it meant that the aristocracy and gentry were not, un-like the majority of the rural population, irrevocably involved, so to speak, bound up in, any particular locality which they had no time, no money, and no reason ever to leave. It meant also that they had experience of more landscapes than one, in more geographical regions than one; and even if they did not travel much, they were accustomed, by their culture, to the notion of mobility, and could easily imagine other landscapes. (qtd. in Bewell 553)

Berrell acknowledges the rural people who are seriously concerned about their local assets of nature and they are completely committed to safeguard and promote their native "landscapes." Unlike so called wealthy and noble people, other local people are found to be interested in preserving "the natural world around them" (Bewell 554).

Bewell strongly appreciates Clare's belief in nature and claims, "For Clare the rights and dignity of nature and rural folk were inseparably bound up with each other and with the local traditions of rural communities" (557). Bewell clearly understands his deal with the relationship between country life and its nature. He further claims:

Clare depicts the concrete and enduring bond between rural laborers and the natural world. His goal is not to present an individual subjective experience of nature (as one finds in the poetry of William Wordsworth), but instead to recover, and thus to preserve, common traditions of experience that had developed over centuries. Tradition is not something that we inherit from the past; instead, it draws its vitality and strength from being constantly renewed or found again in the present. In [his] poems Clare presents a nature that is continuous with the present, a nature that does not change, even though, in the modern world, it struggles to endure. (557)

Clare, through his poetry, tends to demonstrate the relationship "between rural laborers and the natural world" to strengthen his mission of cultivating recovery and preservation of existing "traditions of experience" inherited from ancestor's" legacy. His anticipation 
is to maintain nature's strength and vitality so that people can continue their harmonious relationship with it. Therefore, when he is away from his native land he gets disappointed and "laments the absence of the world that had sustained him and, with it, the slipping away of his identity" (Helsinger 122).

Clare attempts to establish symbiotic relationship between nature and human beings. We need pure water and we keep its sources neat and clean; people plant trees and in some cultures, stones, trees and rivers are worshiped. There are unlimited benefits of clean air, trees, rivers, stones and other natural things. Therefore, Clare symbolically indicates their benefits through his poetic dictions. At the same time, he urges to save them for the better future of this world. He feels disappointed to see the adverse situation brought by human activities in nature. In this context, Hugh Roberts is right to question, "How can we explain such recklessness? We were trying to improve the world! Is it enough to say that we fell under the spell of ideas that were tragically wrong? Those ideas are now so pervasive they are as much habit as belief. We set out to make paradise on earth, and have achieved the opposite" (New York Times).

Clare's vigorous efforts to maintain harmony between nature and human beings cultivate "a sense of belonging" and it helps in strengthening the ties between them. "The attendant joy is what links all human beings to the earth and gives them a sense of belonging" (Bewell 558). Bewell rightly quotes William Blake, "To create a little flower is the labour of ages" (qtd. in Bewell 558) and says, "Clare sees the plant and its joys as being continuous across time" (558).

Clare enjoys the wilderness of nature and displays his anticipation to preserve it so that present and forthcoming generation can see it and lead their life in happy mood. Patricia M. Ball has correctly appreciated Clare's "role as rural spokesman or as pathetic victim of social mismanagement" because he "transcend[s] the descriptive and use[s] his close knowledge of birds and trees and all country life to achieve a more developed vision relating, in the Romantic way, the inner to the outer world" (312). In "Robins Nest," Clare expresses his feelings:

Where old neglect lives patron \& befriends Their homes with safetys wildness — where nought lends A hand to injure - root up or disturb The things of this old place. (qtd. in Bewell 565, 50-53)

Clare feels broken when he finds the disturbances in "wildness," for these disturbances are created by human beings activities in the name if so called modern advancement. Nevertheless, he doesn't lose hope and anticipates the time "[when] human beings can 
106 THE BATUK : A Peer Reviewed Journal of Interdisciplinary Studies $\quad$ Vol. $6 \quad$ Issue No. 2 July 2020 ISSN 2392-4802 still cultivate a community with wild things" (Bewell 565). To strengthen his voice, Clare further expresses:

In heart content on these dead teazle burs

He sits [\&] trembles oer his under notes

So rich-joy almost choaks his little throat

With extacy \& from his own heart flows

That joy himself \& partner only knows (70-75)

Because "all of his needs are satisfied here" (Bewell 566) and real satisfaction is understood by none but by "himself \&" his "partner." Here, Clare talks about the birds and their perception metaphorically to emphasize the situation of human beings and their intentions in the modern age. And, ultimately, he attempts to maintain harmony between human beings and natural world.

In conclusion, Clare takes nature as a source of inspiration and peace. He gets inspiration and encouraging situations from natural world whenever he is in trouble and disturbed by the people around him. He warmly gets vitality and strength when he is with nature. $\mathrm{He}$, through his poetic expression, attempts to establish affinity between people and nature to achieve peace. Therefore, his poems indicate his firm belief in nature and natural activities that bless human beings with meaningful and peaceful life. Such belief in nature ultimately enables people to evaluate the necessity of nature for them and it enhances the strong affinity between nature and human beings.

\section{Works Cited}

Ball, Patricia M. “John Clare by William Howard” The Yearbook of English Studies. Vol. 15. Anglo-French Literary Relations Special Number (1985): 312-13.

Web. 16 January. 2017. <http://www.jstor.org/stable/3508602>.

Barrell, John. The Idea of Landscape and the Sense of Place, 1730-1840: An Approach to the Poetry of John Clare. Cambridge University Press, 1972. 63.

Bewell, Alan. "John Clare and the Ghosts of Natures Past." Nineteenth-Century

Literature. 65.4 (March 2011): 548-578. Web. 16 Jan. 2017.

$<$ http://www.jstor.org/stable/10.1525/ncl.2011.65.4.548>.

Clare, John. The Autobiography, 1793-1824, in The Prose of John Clare. Eds. J. W.

Tibble and Anne Tibble. Routledge and Kegan Paul, 1951. 20.

---. "I am." The Norton Anthology Poetry. $5^{\text {th }}$ ed. Eds. Margaret Ferguson, Mary Jo Salter and Jon Stallworthy. W. W. Norton \& Company, 2005. 896.

---. “Gypsies.” The Norton Anthology Poetry. $5^{\text {th }}$ ed. Eds. Margaret Ferguson, Mary Jo

Salter and Jon Stallworthy. W. W. Norton \& Company, 2005. 894. 
---. "From The Natural History Prose Writing of John Clare." Nature Writing: The Tradition in English. Eds. Robert Finch and John Elder. W. W. Norton \& Company, 2002. 123-128.

---. "Song: Love Lives beyond the Tomb." The Norton Anthology Poetry. $5^{\text {th }}$ ed. Eds. Margaret Ferguson, Mary Jo Salter and Jon Stallworthy. W. W. Norton \& Company, 2005. 894-95.

Finch, Robert and John Elder, eds. Nature Writing: The Tradition in English. W. W. Norton \& Company, 2002.

Green, David Bonnell. "New Letters of John Clare to Taylor and Hessey: 11 December, 1922-25 February." Studies in Philology. 64. 5 (Oct. 1967):720-734. Web. 16 Jan. 2017. <http://www.jstor.org/stable/4173585>.

Helsinger, Elizabeth. Modern Philology.113.2 (November 2015): E122-E125. Web. 16 Jan. 2017. <http://www.jstor.org/stable/10.1086/682128>.

Robert, Hugh. "This Earth Day, We should Repent." New York Times, 20 April 2020. Web. 20 April 2020.

Rueckert, William. "Literature and Ecology: An Experiment in Ecocriticism." The Ecocentricism Reader: Landmarks in Literary Ecology. Eds. Glotfelty Cheryll, and Harold Fromm. University of Georgia Press, 1996. 105-123.

West, Cornel. "Beyond Multiculturalism \& Eurocentrism." African American Literature. Eds. Keith Gilyard and Anissa Jainine Wardi. Penguin Academics, 2004. 1017-31. 